\title{
Trijų vaistų derinys viename inhaliatoriuje gydyti lètinei obstrukcinei plaučiu ligai. TRIBUTE klinikinio tyrimo duomenys
}

\author{
INHALED TRIPLE THERAPY IN CHRONIC OBSTRUCTIVE PULMONARY DISEASE: \\ TRIBUTE CLINICAL STUDY DATA
}

\author{
VIRGINIJA KALINAUSKAITE்-ŽUKAUSKE் \\ LSMU MA Pulmonologijos klinika
}

\begin{abstract}
Santrauka. Lètinei obstrukcinei plaučiu ligai (LOPL) büdingi nuolatiniai respiraciniai simptomai, išliekanti bronchu obstrukcija. Sunkèjant ligai, dažnèja paūmèjimai, reikšmingai įtakojantys gyvenimo kokybę, spartinantys ligos progresavima. Skiriant dviguba LOPL gydymo terapiją, dažnai nepavyksta suretinti ligos paūméjimų. TRIBUTE tyrimo duomenimis, gydymas trimis skirtingu farmakoterapiniu grupiu ìkvepiamaisiais vaistais yra pranašesnis už dviguba terapija dviem bronchus plečiamaisiais vaistais: reikšmingai suretino vidutinio sunkumo - sunkiu LOPL paūmèjimu dažnị. Gydymo metu pastebèta geresnè su sveikata susijusi gyvenimo kokybè, plaučiu funkcija, nenustatyta saugumo profilio skirtumu. Analizuojant gydymo rezultatus, pastebèta, kad gydymas beklometazono dipropionatu, formoterolio fumaratu ir glikopironiu $(B D P / F F / G)$ itin veiksmingas esant lètinio bronchito LOPL fenotipui su padidejusiu periferinio kraujo eozinofily kiekiu (>2 proc.). Toks gydymas turi perspektyva atrinktu pacientu ilgalaikiam LOPL gydymui.
\end{abstract}

Reikšminiai žodžiai: lètinè obstrukcinè plaučiu liga, paūmèjimai, triguba terapija, TRIBUTE klinikinis tyrimas. Summary. Chronic obstructive pulmonary disease (COPD) is characterised by persistent respiratory symptoms and airflow limitation. Due to disease severity, exacerbations, exacerbations, affecting the quality of life, become more frequent, accelerate the progression of the disease. Dual therapy is often insufficient to reduce frequency of COPD exacerbation. Treatment with three different pharmacotherapeutic groups of inhaled medications is superior to dual bronchodilator therapy (TRIBUTE clinical study data): a significant reduction in the moderate-to-severe COPD exacerbations. It was observed improvement of health-related quality of life, lung function, without differences in safety profile. Also, in the analysis of the results, it was observed that $B D P$ / FF / G treatment was particularly effective in the presence of chronic bronchitis COPD phenotype with elevated peripheral blood eosinophil (>2\%). Such treatment is promising for long-term treatment of COPD in carefully selected patients.

Key words: chronic obstructive pulmonary disease; exacerbations, triple therapy, TRIBUTE clinical study.

\section{IVADAS}

Lètinei obstrukcinei plaučių ligai (LOPL) būdingi nuolatiniai kvèpavimo simptomai ir persistuojanti bronchų obstrukcija. Ligai progresuojant, respiraciniai simptomai ryškejja, dažnèja ligos paūmèjimai. Pagrindinis veiksnys ligos patogenezeje, lemiantis kvėpavimo takų obstrukciją, struktūrinius kvėpavimo takų ir plaučių audinio pokyčius, yra lètinis uždegimas.

Visuotinès obstrukcinès plaučių ligos iniciatyva (angl. Global Initiative for Obstructive Lung Disease) rekomenduoja LOPL gydymui skirti trigubą terapiją ilgo veikimo $\beta 2$-agonistu (IVBA), ilgo veikimo muskarino receptorių blokatoriumi (IVMA) ir ịkvepiamuoju gliukokortikoidu (iGK), kai, nepaisant skiriamo gydymo IVBA su IVMA arba IVBA su iGK, toliau stebimi ligos paūmèjimai. Klinikinèje praktikoje dažniausiai taikomas tri- gubas gydymas, tačiau stinga pagrịstų naudos ir rizikos santykio įrodymų, kad LOPL gydymas trimis skirtingu farmakoterapinių grupių įkvepiamaisiais vaistais yra pranašesnis lyginant su dviguba terapija. Ypač svarbu, kad iki šiol neatlikta né vieno klinikinio tyrimo, tiesiogiai lyginusio trigubos ir dvigubos ịkvepiamųju vaistų terapijos viename inhaliatoriuje veiksmingumą gydant LOPL. Triguba terapija viename inhaliatoriuje yra naujiena Lietuvos rinkoje. Viename inhaliatoriuje talpinamas iGK beklometazono dipropionatas, IVBA formoterolio fumaratas ir IVMA glikopironis (BDP/ FF/G). Vaistų inhaliavimo prietaisas tinkamas netgi labai sunkia LOPL sergantiems asmenims, nes sukuria itin smulkias įkvepiamąsias daleles su vidutiniu masès medianos aerodinaminiu diametru $<2 \mu \mathrm{m}$.

$\mathrm{BDP} / \mathrm{FF} / \mathrm{G}$ veiksmingumas ir saugumas iki šiol 
Farmakoterapija

1 lentelè. Demografiniai ir klinikiniai TRIBUTE tyrimo tiriamujų duomenys

\begin{tabular}{|c|c|c|}
\hline & BDP/FF/G (n=764) & IND/GLY ( $n=768)$ \\
\hline $\begin{array}{l}\text { Lytis } \\
\text { Vyras } \\
\text { Moteris }\end{array}$ & $\begin{array}{l}548 \text { (72 proc.) } \\
216 \text { (28 proc.) }\end{array}$ & $\begin{array}{l}552 \text { (72 proc.) } \\
216 \text { (28 proc.) }\end{array}$ \\
\hline $\begin{array}{l}\text { Rasè } \\
\text { Baltoji } \\
\text { Kita }\end{array}$ & $\begin{array}{c}705 \text { (92 proc.) } \\
51 \text { (7 proc.) }\end{array}$ & $\begin{array}{c}708 \text { (92 proc.) } \\
52 \text { (7 proc.) }\end{array}$ \\
\hline Amžius (metais) & $64,4(7,7)$ & $64,5(7,7)$ \\
\hline Kūno masės indeksas (kg/m²) & $25,7(5,1)$ & $26,6(5,4)$ \\
\hline Leukocitų kiekis periferiniame kraujyje ( $10^{9}$ ląstelių/l) & $8,05(2,38)$ & $8,00(2,04)$ \\
\hline Eozinofilų kiekis periferiniame kraujyje ( $10^{9}$ ląstelių/l) & $0,24(0,20)$ & $0,23(0,20)$ \\
\hline Kraujo eozinofilai & 3,14 proc. $(2,47)$ & 2,97 proc. $(2,30)$ \\
\hline $\begin{array}{l}\text { Rūkymo statusas } \\
\text { Rūkęs anksčiau } \\
\text { Rūkantis }\end{array}$ & $\begin{array}{l}413 \text { (54 proc.) } \\
351 \text { (46 proc.) }\end{array}$ & $\begin{array}{l}436 \text { (57 proc.) } \\
332 \text { (43 proc.) }\end{array}$ \\
\hline Laikas nuo LOPL diagnozės patvirtinimo (metais) & $8,16(5,76)$ & $7,99(5,64)$ \\
\hline $\mathrm{FEV}_{1}(\mathrm{l})$ & $1,07(0,31)$ & $1,07(0,31)$ \\
\hline $\begin{array}{l}\text { FEV }_{1} \text { pasiskirstymas pagal būtinaji dydi } \\
\quad<30 \text { proc. } \\
\quad \geq 30 \text { proc. iki }<50 \text { proc. }\end{array}$ & $\begin{array}{c}36,4(8,0) \\
154 \text { (20 proc.) } \\
609 \text { (80 proc.) }\end{array}$ & $\begin{array}{c}36,4(8,1) \\
160 \text { (21 proc.) } \\
608 \text { (79 proc.) }\end{array}$ \\
\hline FVC (I) & $2,70(0,78)$ & $2,64(0,77)$ \\
\hline $\mathrm{FEV}_{1} / \mathrm{FVC}$ & $0,41(0,10)$ & $0,42(0,10)$ \\
\hline Grį̌tamumas ( proc.) & 8,4 proc. $(13,5)$ & 8,8 proc. $(13,5)$ \\
\hline \multicolumn{3}{|l|}{ Klinikinis LOPL fenotipas } \\
\hline Lètinis bronchitas & 434 (57 proc.) & 421 (55 proc.) \\
\hline Emfizema & 227 (30 proc.) & 235 (31 proc.) \\
\hline Mišrus lètinio bronchito ir emfizemos fenotipas & 103 (13 proc.) & 112 (15 proc.) \\
\hline $\begin{array}{l}\text { Vidutinio sunkumo arba sunkus paūmèjimas per } \\
\text { praèjusius metus } \\
\quad 1 \\
\quad \geq 2\end{array}$ & $\begin{array}{l}1,2(1-6) \\
612 \text { (80 proc.) } \\
152(20 \text { proc.) }\end{array}$ & $\begin{array}{l}1,2(1-4) \\
626(82 \text { proc. }) \\
142(18 \text { proc.) }\end{array}$ \\
\hline $\begin{array}{l}\text { LOPL vaistai, vartoti ne trumpiau kaip } 2 \text { mèn. iki } \\
\text { tyrimo pradžios } \\
\text { iGK/IVBA } \\
\text { iGK/IVMA } \\
\text { IVBA/IVMA } \\
\text { IVMA }\end{array}$ & $\begin{array}{l}467 \text { (61 proc.) } \\
36 \text { (5 proc.) } \\
183 \text { (24 proc.) } \\
77 \text { (10 proc.) }\end{array}$ & $\begin{array}{l}465 \text { (61 proc.) } \\
24 \text { (3 proc.) } \\
199 \text { (26 proc.) } \\
80 \text { (10 proc.) }\end{array}$ \\
\hline $\begin{array}{l}\text { Tiriamieji, turintys bent vieną gretutinę patologiją } \\
\text { Hipertenzija } \\
\text { Išeminė širdies liga } \\
\text { Miokardo išemija } \\
\text { Koronarinè širdies liga } \\
\text { Krūtinės angina } \\
\text { Miokardo infarktas } \\
\text { Išeminė kardiomiopatija } \\
\text { Cukrinis diabetes } \\
\text { Širdies nepakankamumas } \\
\text { Hipercholesterolemija } \\
\text { Dislipidemija } \\
\text { Gerybinė prostatos hiperplazija } \\
\text { Nutukimas } \\
\text { Gastroezofaginio refliukso liga } \\
\text { Hiperlipidemija }\end{array}$ & $\begin{array}{l}644 \text { (84 proc.) } \\
437 \text { (57 proc.) } \\
134 \text { (18 proc.) } \\
69 \text { (9 proc.) } \\
42 \text { (5 proc.) } \\
32 \text { (4 proc.) } \\
3 \text { (<1 proc.) } \\
1 \text { (<1 proc.) } \\
99 \text { (13 proc.) } \\
75 \text { (10 proc.) } \\
58 \text { (8 proc.) } \\
64 \text { (8 proc.) } \\
49 \text { (6 proc.) } \\
33 \text { (4 proc.) } \\
35 \text { (5 proc.) } \\
23 \text { (3 proc.) }\end{array}$ & $\begin{array}{l}657 \text { (86 proc.) } \\
460 \text { (60 proc.) } \\
156 \text { (20 proc.) } \\
75 \text { (10 proc.) } \\
63 \text { (8 proc.) } \\
27 \text { (4 proc.) } \\
0 \\
1 \text { (<1 proc.) } \\
108 \text { (14 proc.) } \\
75 \text { (10 proc.) } \\
65 \text { (8 proc.) } \\
56 \text { (7 proc.) } \\
35 \text { (5 proc.) } \\
49 \text { (6 proc.) } \\
45 \text { (6 proc.) } \\
47 \text { (6 proc.) }\end{array}$ \\
\hline
\end{tabular}

Duomenys pateikiami kaip n (proc.) arba vidurkis (SN), jei nenurodyta kitaip. BDP/FF/G - beklometazono dipropionatas, formoterolio fumaratas ir glikopironis; $\mathrm{FEV}_{1}$ - forsuoto iškvèpimo tūris per pirmają sekundę (angl. Forced Expiratory Volume in 1 Second); FVC - forsuota gyvybinè plaučiu talpa (angl. Forced Vital Capacity), iGK - ikvepiamasis gliukokortikoidas; IND/GLY - indakaterolis ir glikopironis; IVBA - ilgo veikimo ß2-agonistas; IVMA - ilgo veikimo muskarino receptorių antagonistas. ivertintas dviejuose 52 savaičiuc trukmès tyrimuose: TRILOGY klinikinio tyrimo metu pastebèta, kad minètų vaistinių preparatų derinys 23 proc. sumažino LOPL paūmèjimų dažnị lyginant su BDP/ FF; TRINITY klinikinio tyrimo rezulatai buvo panašūs LOPL paūmèjimai buvo 20 proc. retesni, tačiau šio tyrimo metu vaistu veiksmingumas palygintas su IVMA tiotropiu. Šiame straipsnyje pateikiami TRIBUTE klinikinio tyrimo duomenys, gauti palyginus $\mathrm{BDP} / \mathrm{FF} / \mathrm{G}$ veiksmingumą su IVBA indakaterolio ir glikopironio deriniu viename inhaliatoriuje (IND/GLY).

Lyginamajai grupei pasirinktas IND/GLY dèl to, kad tai vienintelis IVBA ir IVMA derinys, kurio veiksmingumas jau įrodytas retinant LOPL paūmejjimus, palyginus su vieną kartą per parą ikvepiamuoju glikopironiu ir du kartus per parą vartojamu flutikazono ir salmeterolio deriniu.

\section{TRIBUTE KLINIKINIO TYRIMO DUOMENYS}

Atliktas atsitiktinių imčių, paralelinių grupių, dvigubai aklas, dvigubai koduotas tyrimas 187 centruose 17 skirtingu šalių. Tyrimui atrinkti pacientai, patiriantys nuolatinius LOPL simptomus, turintys išreikštą bronchų obstrukciją (pagal LOPL sunkumą atitinkantys sunkią ir labai sunkią ligą, forsuoto iškvèpimo tūris per pirmąą sekundę (angl. Forced Expiratory Volume in 1 Second, $\left.\mathrm{FEV}_{1}\right)<50$ proc.), per praejusius metus patyrę bent vieną vidutinio sunkumo arba sunku paūmejjimą nepaisant nuolat skiriamo palaikomojo gydymo.

Pirminè vertinamoji baigtis buvo vidutinio sunkumo LOPL paūmèjimų dažnis per 52 gydymo tiriamuoju vaistu 
savaites. Antrinès vertinamosios baigtys: laikas iki pirmo vidutinio arba sunkaus paūmejjimo ir laikas iki pirmo sunkaus LOPL paūmėjimo; sunkių ir vidutinio sunkumo LOPL paūmèjimų dažnis; $\mathrm{FEV}_{1}$, forsuotos gyvybinès plaučiu talpos (angl. Forced Vital Capacity, FVC) ir šv. Jurgio kvejpavimo klausimyno (angl. the Saint George's Respiratory Questionnaire, SGRQ) ivvertis kiekvieno tyrimo vizito metu prieš įkvepiant kitą tiriamo vaisto dozę ir minètų rodiklių vidurkis per visą gydymo laikotarpi, $\mathrm{FEV}_{1}$ atsakas (pokytis nuo pradinès reikšmės $\geq 100 \mathrm{ml}$ ) ir šv. Jurgio kvẻpavimo klausimyno balo pokytis (sumažejjimas nuo pradinio lygio $\geq 4$ ) 26-ąją ir 52-ąją savaitès; skubios pagalbos simptomus slopinamųjų vaistų vartojimas; EXACT kvèpavimo simptomų vertinimas balais (remiantis 11 pagrindinių klausimų iš EXACT-PRO klausimyno, ir LOPL vertinimo testo bendrasis balas (angl. COPD Assessment Test, CAT) gydymo pabaigoje.

LOPL paūmėjimas buvo apibrèžiamas kaip ilgalaikis kvejpavimo simptomų pablogèjimas, kai reikia skirti gydymą sisteminiais GK, antibiotikais arba stacionarizuoti. Paūmèjimų sunkumas vertintas remiantis Europos vaistų agentūros Žmogaus vartojamų medicinos produktų komiteto (angl. European Medicines Agency Committee for Medicinal Products for Human Use) rekomendacijomis. Sunkiu laikytas paūmejjimas, kai gydymas galimas tik stacionare arba LOPL sąlygotas būklès pablogèjimas baigdavosi mirtimi. Siekiant geriau prognozuoti artejantị ligos paūmèjimą, tyrimo metu naudotas EXACT-PRO klausimynas (elektroninis dienynas, kurio pagalba, blogejjant simptomams, tiriamasis aktyviai skatintas susisiekti su tyrimo tyrèju).

Viso tyrimo metu buvo registruojami nepageidaujami reiškiniai, kuriais pripažinti pasireiškę vaisto vartojimo metu arba po pirmos vaisto dozès. Saugumo profilis vertintas visiems pacientams, kurie tyrimo metu gavo mažiausiai vieną skiriamų vaistų dozę.

Po dviejų savaičių gydymo viena IND/GLY $(85 / 43 \mu \mathrm{g})$ inhaliacija per dieną, tiriamieji atsitiktine tvarka santykiu 1:1 suskirstyti ị tiriamąsias grupes: 52 savaites tęstos IND/GLY $(85 / 43 \mu \mathrm{g})$ inhaliacijos vieną kartą per dieną arba skirtas BDP/FF/G $(87 / 5 / 9 \mu \mathrm{g})$ po dvi inhaliacijas du kartus per parą per itin smulkias ¡kvepiamąsias daleles sukuriantị inhaliatorių. Randomizacija buvo vykdoma tiek pagal šalį, tiek pagal bronchų obstrukcijos sunkumą.

Tyrimas truko kiek daugiau nei dvejus metus. Iš viso ị tyrimą pakviesti 2103 asmenys, iš kurių ị tiriamąsias grupes atsitiktine tvarka suskirstyti 1532. Tyrimą baigè 666 (87 proc.) iš 764 pacientų, kuriems buvo skirtas gydymas BDP/FF/G ir 648 (84 proc.) iš 768 pacientų, inhaliavusių IND/GLY (1 pav.). Tiriamieji tinkamai laikèsi vaistų vartojimo režimo - BDP/FF/G grupèje vaistų suvartojimas siekè 98,6 proc., IND/GLY gru- pèje - 98,4 proc. Išsamūs tiriamųjų demografiniai ir klinikiniai duomenys pateikti 1 lentelèje.

Pacientams, vartojusiems $\mathrm{BDP} / \mathrm{FF} / \mathrm{G}$, nustatytas koreguotas vidutinio sunkumo ir sunkių LOPL paūmèjimų dažnis buvo 0,50 paūmejjimo pacientui per metus (95 proc. pasikliautinasis intervalas (PI) 0,45-0,57), IND/GLY grupejje - 0,59 (95 proc. PI 0,53-0,67) (1 pav.). Vidutinio sunkumo ir sunkių LOPL paūmèjimų dažnis buvo gerokai mažesnis BDP/FF/G nei IND/ GLY grupeje, esant koreguotam dažnio santykiui 0,848 (95 proc. PI 0,723-0, 995; $\mathrm{p}=0,043$ ), pažyminčiam 15 proc. retesnius LOPL paūmèjimus (2 pav.). Aktyviai tyrime dalyvavusių tiriamųjų (angl. The Perprotocol Population) duomenys, vertinant pirminę vertinamąją baigti, buvo palyginti su numatytų gydyti pacientų populiacijos (angl. Intent-To-Treat Population, ITT) rezultatais, tačiau dažnio santykis reikšmingai nesiskyrè (koreguotas dažnio santykis - 0,849, 95 proc. PI $0,721-1,000, p=0,050)$. Pirminès baigties analizei tiriamieji suskirstyti ị pogrupius. Sergantiesiems LOPL su išreikštu lètiniu bronchitu ir gydytiems BDP/FF/G deriniu paūmèjimų dažnis buvo reikšmingai mažesnis, palyginus su asmenimis, inhaliavusiais IND/GLY $(0,752,95$ proc. PI $0,605-0,935, \mathrm{p}=0,010)$, tuo tarpu su dominuojančia emfizema LOPL sergantiems asmenims koreguotas dažnio santykis buvo 0,995 (95 proc. PI $0,754-1,314, \mathrm{p}=0,974)$, mišraus LOPL pogrupio (emfizema + lètinis bronchitas) - 0,939 (95 proc. PI $0,605-1,459, \mathrm{p}=0,781)$. Pastebèta, kad LOPL paūmè-

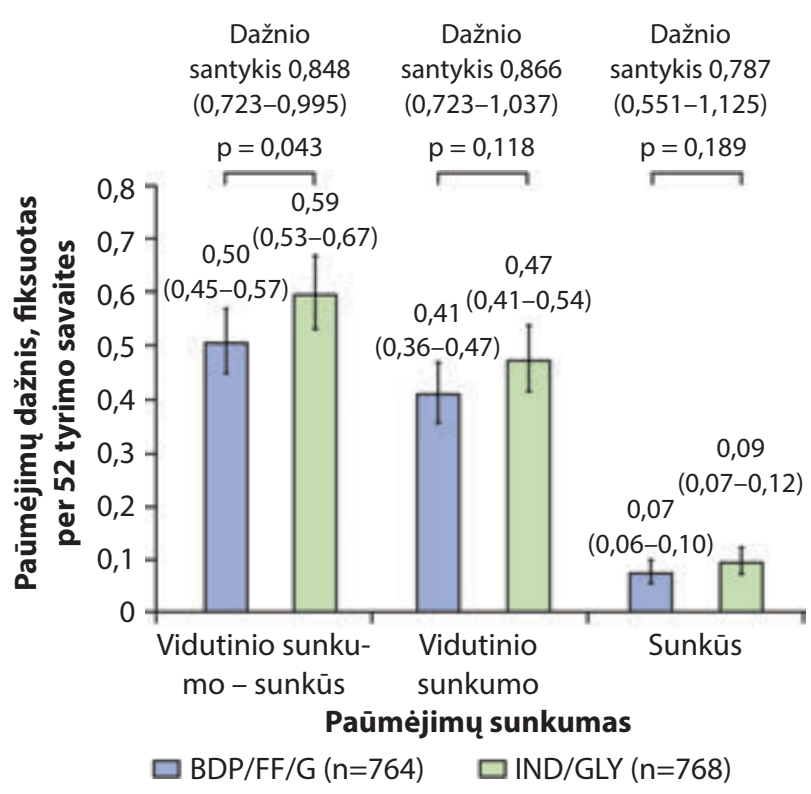

1 pav. Koreguotas vidutinio sunkumo - sunkių, vidutinio sunkumo ir sunkių LOPL paūmèjimų dažnis. Analizė atlikta numatytų gydyti tiriamuoju vaistiniu preparatu populiacijoje. Paūmèjimų dažnis ir dažnio santykis pateikiami 95 proc. pasikliautinojo intervalo ribose

BDP/FF/G - beklometazono dipropionatas, formoterolio fumaratas ir glikopironis; IND/GLY - indakaterolis ir glikopironis. 


\section{Farmakoterapija}

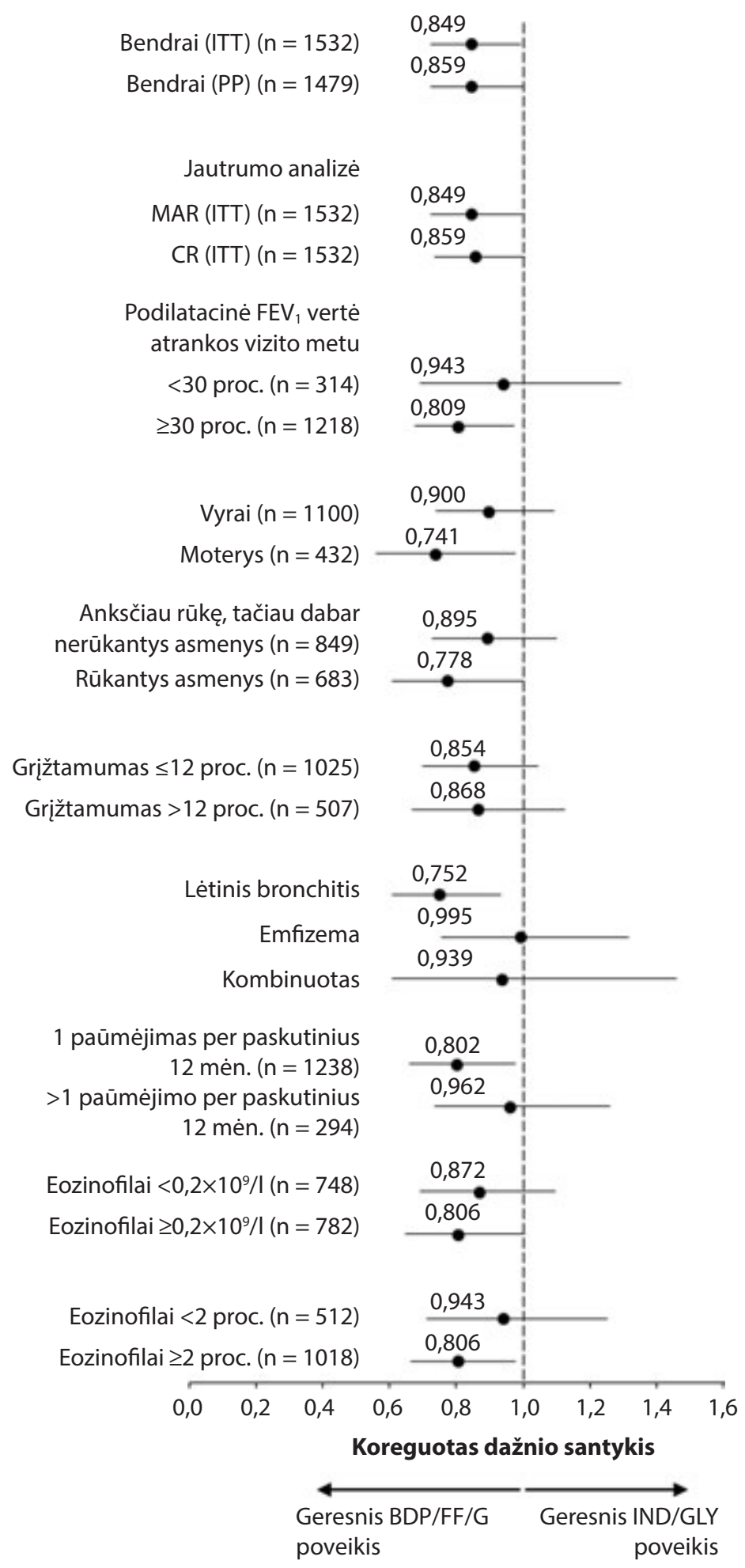

2 pav. Vidutinio sunkumo ir sunkių LOPL paūmèjimų koreguotas dažnio santykis (95 proc. pasikliautinasis intervalas)

BDP/FF/G - beklometazono dipropionatas, formoterolio fumaratas ir glikopironis; FEV forsuoto iškvejpimo tūris per pirmają sekundę (angl. Forced Expiratory Volume in 1 Second); IND/GLY - indakaterolis ir glikopironis; ITT - numatytu gydyti pacientu populiacija (angl. Intent-To-Treat Population, ITT); PP - tyrime dalyvavusių tiriamuju populiacija (angl. the Perprotocol Population) jimai buvo reikšmingai retesni ihaliuojant $\mathrm{BDP} / \mathrm{FF} / \mathrm{G}$ nei IND/GLY ir tiems LOPL sergantiesiems, kuriems periferiniame kraujyje nustatytas $\geq 2$ proc. eozinofilų kiekis $(0,806,95$ proc. PI $0,664-0,978 ; \mathrm{p}=0,029)$, kartu su 0,943 koreguotu dažnio santykiu (95 proc. PI $0,711-1,251, \mathrm{p}=0,685$ ) tiriamiesiems, kurių eozinofilų kiekis mažesnis nei 2 proc. Atliekant papildomą analizę, tiriamuosius suskirstant ị pogrupius pagal absoliutu periferinio kraujo eozinofilu kiekí, koreguotas dažnio santykis $\geq 200$ ląstelių/ $\mu$ l pogrupyje buvo 0,806 (95 proc. PI 0,646-1,007, $\mathrm{p}=0,057),<200$ ląstelių/ $\mu \mathrm{l}$ pogrupyje $-0,872$ (95 proc. PI $0,692-1,098$, $\mathrm{p}=0,244)(2$ pav. $)$.

Atskirai analizuoti vidutinio sunkumo ir sunkių LOPL paūmèjimų dažniai BDP/ FF/G ir IND/GLY grupèse reikšmingai nesiskyrè - atitinkamai buvo 13 ir 21 proc. (1 pav.). Laikas iki pirmo vidutinio arba sunkaus paūmejimo taip pat buvo panašus (rizikos santykis (RS) 0,901, 95 proc. PI 0,763-1,064, $\mathrm{p}=0,219$ ), kaip ir laikas iki pirmo sunkaus paūmèjimo (RS 0,864, 95 proc. PI 0,613-1,219, $\mathrm{p}=0,405)$.

Koreguotas vidutinis $\mathrm{FEV}_{1}$ pokytis, lyginant su pradinio vizito vertemis, 12 -ąją, 40-ajją gydymo savaitę ir per visą gydymo laikotarpi buvo žymiai didesnis BDP/ FF/G grupeje nei inhaliavusiems IND/ GLY (3 pav. A). Rezultatai atsispindejo ir tiriamiesiems pildant šv. Jurgio kvèpavimo klausimyną, kurio vidutinis bendrasis balas labiau sumažejo gydytiems BDP/FF/G nei IND/GLY (3 pav. B). Vertinant gydymo atsaką 26-ąją ir 52-ąją gydymo savaitę pagal $\mathrm{FEV}_{1}$ ir šv. Jurgio kvejpavimo klausimyno balo pokyčius nuo pradinio vizito, geresnių gydymo rezultatų pasieké didesné BDP/ FF/G nei IND/GLY grupès tiriamųjų dalis, nors šansų santykis statistiškai reikšmingai nesiskyrè. Koreguotas vidutinis FVC pokytis abejose tiriamuju grupèse buvo panašus, tačiau 40-ąją gydymo savaitę buvo kiek didesnis įkvepiant BDP/FF/G nei IND/GLY. LOPL vertinimo testo balo vidurkio pokytis gydymo pabaigoje buvo $-0,8 \mathrm{BDP} / \mathrm{FF} / \mathrm{G}$ grupeje ir -0,6 IND/GLY grupeje.

Vaistu vartojimas skubiam simptomų slopinimui (pagal ịkvépimų kiekị per dieną ir procentinę dienų dalį, kai šio tipo vaistų 


\section{Farmakoterapija}

inhaliuoti nereikèjo) abejose tiriamųjų grupèse buvo panašus. Palyginus su IND/GLY grupès pacientais, $\mathrm{BDP} / \mathrm{FF} / \mathrm{G}$ inhaliavę asmenys per pirmąsias 12 tyrimo savaičių pastebejo gerokai didesnį EXACT kvejpavimo simptomų balų pagerèjimą, palyginus su pradiniu vizitu, tačiau tolesnių apsilankymų metu šis ịvertis nežymiai išsiskyrè.

Saugumas pagal lengvo ir vidutinio sunkumo nepageidaujamus reiškinius tiek $\mathrm{BDP} / \mathrm{FF} / \mathrm{G}$, tiek IND/ GLY grupése buvo panašus. Registruoti 28 (4 proc.) pneumonijos atvejai BDP/FF/G grupeje ir 27 (4 proc.) IND/GLY grupeje, daugiau kaip 80 proc. šiu atveju diagnozuoti vizualiniais tyrimais (24 (75 proc.) BDP/ FF/G grupeje ir 26 (90 proc.) IND/GLY grupèje). Širdies ir kraujagyslių sistemos nepageidaujamų reiškinių dažnis tiriamosiose grupèse taip pat buvo panašus: 44 tiriamiesiems (6 proc.), vartojusiems BDP/FF/G, ir 51 (7 proc.) IND/GLY grupès tiriamajam. Sunkūs nepageidaujami reiškiniai buvo reti ir pasireiškimo dažniu tarp tiriamųjų grupių ženkliau nesiskyrè - 11 pacientų (1 proc.), gydytu BDP/FF/G ir 29 tiriamiesiems (4 proc.), inhaliavusiems IND/GLY. Kiekvienoje tiriamojoje grupèje i̇vyko po vieną sunkų nepageidaujamą reiškinị, siejamą su tiriamuoju vaistu - dizurija BDP/ FF/G grupeje ir prieširdžių virpèjimas IND/GLY grupèje. Nepageidaujami reiškiniai, dẻl kurių teko nutraukti skiriamą gydymą, buvo retesni BDP/FF/G grupeje lyginant su IND/GLY grupe. Dažniausia tiriamojo vaisto nutraukimo priežastimi įvardytas LOPL paūmèjimas (5 pacientams $\mathrm{BDP} / \mathrm{FF} / \mathrm{G}$ grupeje ir 10 pacientų IND/ GLY grupeje). 37 atvejais nepageidaujami reiškiniai baigèsi mirtimi, tačiau nè vienas jų nebuvo siejamas su tiriamuoju vaistu. Kraujospūdžio, širdies susitraukimų dažnio ir kitų EKG parametrų pokyčiai, palyginus su pradinio vizito metu išmatuotomis vertèmis, kliniškai reikšmingai nepakito ir grupèse pagal dažnį neišsiskyrè.

Apibendrinus tyrimo rezultatus įvairiuose pogrupiuose, pastebèta, kad santykinai retesni vidutinio sunkumo arba sunkūs LOPL paūmèjimai buvo BDP/ FF/G grupeje, gydant lètinio bronchito fenotipą turinčius LOPL sergančiuosius, kurių periferinio kraujo eozinofilų kiekis buvo $>2$ proc. Šie rezultatai atitiktų keletą tikslinių ir aposteriorinių (angl. post-hoc) analizių duomenis, kai LOPL paūmèjimus retinantis iGK poveikis buvo geresnis asmenims, turintiems didesni periferinio kraujo eozinofilų kiekị. TRIBUTE tyrimo metu ribiné eozinofilų vertè, pagal kurią skirstyta i pogrupius, buvo 200 ląstelių/ $\mu$ l, tačiau, nesant konkrečių rekomendacijų, koks turètų būti eozinofilų ribinis kiekis, rezultatai turi būti interpretuojami neabsoliučiai. Reikalingi tęstiniai tyrimai. Gauti rezultatai galètų prisidèti aiškinant tam tikrus nesèkmingo LOPL gydymo IVBA ir IVMA derinio aspektus, kai, pridejus iGK, sèkmingiau valdomi ligos paūmèjimai.

Trigubos terapijos viename inhaliatoriuje nauda yra

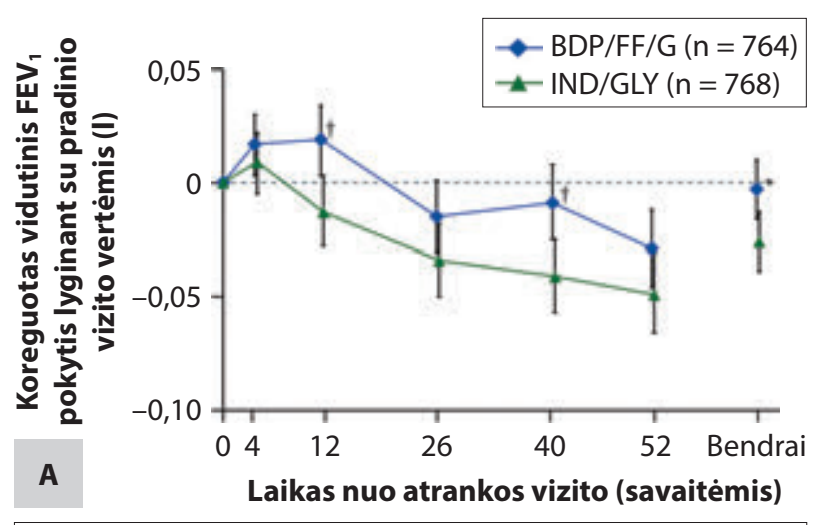

Koreguotas vidutinis skirtumas tarp gydymo grupių (ml) $\begin{array}{llllll}8 & 32 & 20 & 32 & 19 & 22\end{array}$

Tiriamujų skaičius, kuriems atliktas vertinimas

BDP/FF/G $761754 \quad 737 \quad 718 \quad 694 \quad 688 \quad 757$

IND/GLY $761754 \quad 742 \quad 712 \quad 677 \quad 652 \quad 760$

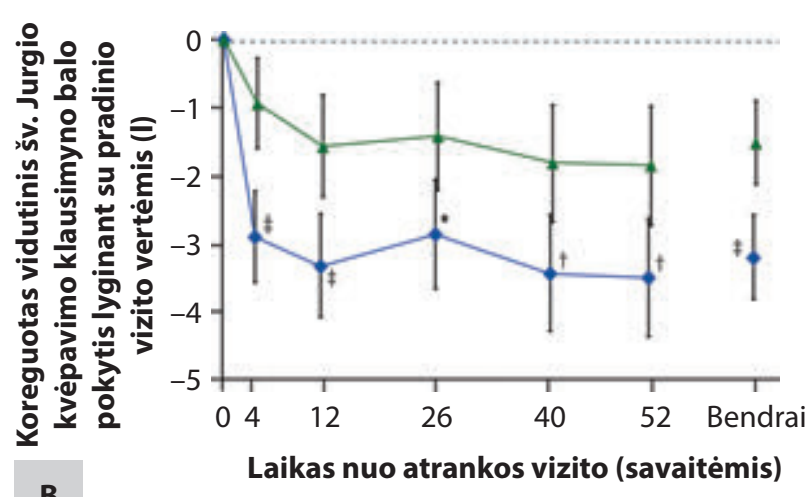

Koreguotas vidutinis skirtumas tarp gydymo grupių (ml) $\begin{array}{lllll}-1,96-1,75 & -1,43 & -1,62 & -1,64 & -1,68\end{array}$

Tiriamujų skaičius, kuriems atliktas vertinimas

BDP/FF/G $763757 \quad 740 \quad 722 \quad 695 \quad 667 \quad 760$

IND/GLY 768744 $744 \quad 716 \quad 679 \quad 657 \quad 763$

3 pav. Koreguotas vidutinis $\mathrm{FEV}_{1}(A)$ ir šv. Jurgio kvejpavimo klausimyno balo (B) pokytis lyginant su pradiniu vizitu

Analizè atlikta numatytu gydyti tiriamuoju vaistiniu preparatu populiacijoje. Paūmèjimu dažnis ir santykio rizika pateikiama 95 proc. pasikliautinojo intervalo ribose.

${ }^{*} p<0,05$ lyginant su IND/GLY; $+p<0,01$ lyginant su IND/GLY; $\neq p \leq 0,001$ lyginant su IND/GLY.

$\mathrm{BDP} / \mathrm{FF} / \mathrm{G}$ - beklometazono dipropionatas, formoterolio fumaratas ir glikopironis; $F_{E V}$ - forsuoto iškvèpimo tūris per pirmają sekundę (angl. Forced Expiratory Volume in 1 Second); IND/GLY - indakaterolis ir glikopironis

ir tai, kad gereja vaistų suvartojimas, kuris priklauso nuo naudojamų inhaliatorių kiekio. Ne mažiau svarbu prietaiso naudojimo paprastumas. Naudojant $\geq 2$ inhaliatorius, didejja rizika suklysti inhialiavimo technikoje (skiriasi prietaisai, jų paruošimas, inhaliavimo technika).

\section{APIBENDRINIMAS}

Tai pirmasis tyrimas, tiesiogiai vertinęs trigubos ir dvigubos LOPL gydymo terapijos viename inhalia- 


\section{Farmakoterapija}

toriuje veiksmingumą retinant LOPL paūmejjimus. Tyrimo rezultatų duomenimis, ne lengvesnio kaip vidutinio sunkumo LOPL $\left(\mathrm{FEV}_{1}<50\right.$ proc.) gydymas triguba terapija su iGK, IVBA ir IVMA viename inhaliatoriuje, sukuriančiame itin smulkias įkvepiamas vaisto daleles, reikšmingai suretino vidutinio sunkumo - sunkių LOPL paūmèjimų dažnị (apie 15 proc.), palyginus su dviguba bronchodilatacine terapija. Gydymo metu pastebèta geresnè su sveikata susiju- si gyvenimo kokybė, ventiliacinė plaučių funkcija. Saugumo skirtumų nenustatyta tiek vertinant visus nepageidaujamus reiškinius, tiek išskiriant pneumonijos atvejus. Analizuojant rezultatus pastebèta, kad gydymas BDP/FF/G itin veiksmingas esant lètinio bronchito LOPL fenotipui su padidejusiu periferinio kraujo eozinofilų kiekiu (>2 proc.). Toks gydymas turi perspektyvą kruopščiai atrinktų pacientų ilgalaikiam LOPL gydymui.

Parengta pagal: Papi A, Vestbo J, Fabbri L, Corradi M, Prunier H, Cohuet G, et al. Extrafine inhaled triple therapy versus dual bronchodilator therapy in chronic obstructive pulmonary disease (TRIBUTE): a double-blind, parallel group. Randomised controlled trial. Lancet. 2018; 391(10125):1076-84. 